\title{
Kinetic Resolution of Protected $\alpha$-Amino Acid Derivatives by a Chiral $O$-Nucleophilic Acyl Transfer Catalyst
}

\author{
Gregory T. Notte and Tarek Sammakia* \\ Department of Chemistry and Biochemistry, University of Colorado, Boulder, Colorado \\ 80309-0215
}

Supporting Information

Table of Contents:

S1-S2 General Information

S2-S6 Synthesis and characterization of compounds 9 to $\mathbf{1 8 .}$

S7 Typical procedure for the kinetic resolutions.

S7-S10 Kinetic resolution of compounds 9 to 18.

S11-S12 Peptide couplings.

S12 Determination of absolute configuration.

S13 Protecting group swap.

S14 Reaction kinetics

S15-S38 ${ }^{1} \mathrm{H}$ and ${ }^{13} \mathrm{C}$ NMR spectra for compounds $\mathbf{9 - 1 8}$ and $\mathbf{2 0}-\mathbf{2 1}$ (separate PDF file).

General Information. All air or moisture sensitive reactions were conducted in oven dried glassware under a dry nitrogen atmosphere. Methanol, triethyl amine, ethyltrifluoroacetate, and methylene chloride were distilled from $\mathrm{CaH}_{2}$. Toluene was washed with concentrated $\mathrm{H}_{2} \mathrm{SO}_{4}, \mathrm{H}_{2} \mathrm{O}, 1 \mathrm{M} \mathrm{NaOH}$, and $\mathrm{H}_{2} \mathrm{O}$, dried over $\mathrm{MgSO}_{4}$, then filtered and distilled from $\mathrm{CaH}_{2}$. Except for the precursor to compound 14, all of the racemic amino acids were available from commercial sources and most were purchased from Fluka or Aldrich. Azetidine-2-carboxylic acid was purchased from Toronto Research, and azepane-2-carboxylic acid was purchased from ASDI. The racemic amino acid 1,2,3,4-tetrahyrdoisoquinoline-1-carboxylic acid was synthesized by reduction of 1isoquinolinecarboxylic acid following the procedure of Schuman. ${ }^{1}$ Flash chromatography of substrate $\mathbf{1 6}(\mathrm{R}=$ isobutyl) was performed on neutral silica gel (Mallinckrodt Silicar Silica Gel 150, 60-200 mesh (75-250 micron)) following the procedure of Still. ${ }^{2}$ Flash chromatography of this substrate on other "ordinary" silica gel (i.e. silica gel with a $\mathrm{pH}$ other than 7.0) led to partial cleavage of the oxazolidinethione auxiliary. All other flash chromatography was performed using Sorbent Technologies 60

1 Shuman R. T.; Rothenberger R. B.; Campbell C. S.; Smith G. F.; Gifford-Moore D. S.; Gesellchen P. D.; J. Med. Chem. 1993, 36, 314-319.

2 Still, W. C.; Kahn, M.; Mitra, A. J. Org. Chem. 1978, 43, 2923. 
$\AA$ silica gel (32-63 micron). ${ }^{1} \mathrm{H}$ NMR spectra were recorded at $400 \mathrm{MHz}$ in $\mathrm{CDCl}_{3}$ and were referenced to residual $\mathrm{CHCl}_{3}(7.24 \mathrm{ppm}) .{ }^{13} \mathrm{C}$ NMR spectra were obtained at 100 $\mathrm{MHz}$ in $\mathrm{CDCl}_{3}$ and were referenced to the center line of the $\mathrm{CDCl}_{3}$ triplet $(77.23 \mathrm{ppm}$ ). Chiral HPLC analysis was performed using a semi-preparative Chiralcel OD column. Compounds were detected by monitoring UV absorbance at $254 \mathrm{~nm}$. Infrared spectra were recorded as thin films on $\mathrm{NaCl}$ plates. Melting points were determined in open capillaries and are uncorrected. Optical rotations were determined on a JASCO 1030 polarimeter at $25{ }^{\circ} \mathrm{C}$. Exact mass was determined on $\mathrm{M}+\mathrm{H}$ or $\mathrm{M}+\mathrm{Na}$ using electrospray ionization.

\section{Synthesis of Substrates:}

\section{General Procedure for Preparation from $\alpha$-Amino Acids}

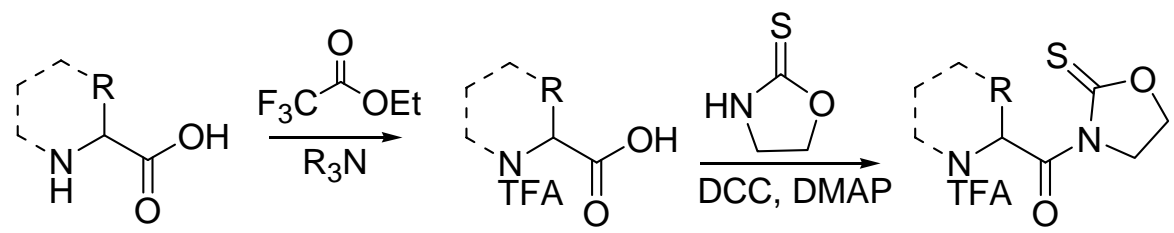

This is a general procedure and some changes were made for specific substrates. In general, tetramethylguanidine was used in the protection of the cyclic amino acids while triethyl amine was used for acyclic amino acids (proline and azetidine-2-carbozylic acid are exceptions). Excess base was also required if starting from the amino acid hyrdochloride salt.

To a stirred solution of the $\alpha$-amino acid $(1.0 \mathrm{mmol})$ in $\mathrm{MeOH}(1.0 \mathrm{ml}, 1.0 \mathrm{M})$ at room temperature was added amine base $(1.0 \mathrm{mmol})$. Ethyltrifluoroacetate $(1.25 \mathrm{mmol})$ was then added to this suspension, and the reaction was stirred at room temperature for 24-48 hours. The reaction progresses from a suspension to a nearly clear solution upon completion. $\mathrm{MeOH}$ was removed under reduced pressure, and the residue was acidified by the addition of a slight excess of $2 \mathrm{M} \mathrm{HCl}$. The aqueous layer was extracted with EtOAc (three times), and the combined organic extracts were washed once with a 10:1 $1 \mathrm{M} \mathrm{HCl} /$ brine solution, then dried over $\mathrm{MgSO}_{4}$, filtered, and concentrated at reduced pressure to a solid. This material was of sufficient purity for use in the subsequent coupling reactions.

To a stirred solution of the crude $N$-TFA protected amino acid prepared above $(1.0 \mathrm{mmol})$, oxazolidinethione $(1.1 \mathrm{mmol})$ and DMAP $(0.10 \mathrm{mmol})$ in $\mathrm{CH}_{2} \mathrm{Cl}_{2}(6 \mathrm{ml}$, $0.1 \mathrm{M}$ overall) at room temperature was cannulated dropwise a solution of DCC in $\mathrm{CH}_{2} \mathrm{Cl}_{2}$ $(4 \mathrm{ml})$. The reaction was monitored by TLC, and was complete in less than $8 \mathrm{hrs}$. The reaction mixture was then filtered to remove dicyclohexyl urea and concentrated at reduced pressure. Purification by flash chromatography (3:1 hexanes-ethyl acetate) affords the product as a white solid. 


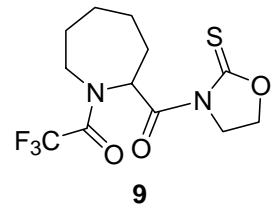

Compound 9 was prepared in $77 \%$ overall yield from the amino acid. Tetramethylguanidine (1.0 equiv) was used as the base in the TFA protection.

${ }^{1} \mathrm{H}$ NMR revealed a 4:1 mixture of conformers $\left(400 \mathrm{MHz}, \mathrm{CDCl}_{3}\right): \delta 6.61(\mathrm{dd}$, $.20 \mathrm{H}, \mathrm{J}=6,10 \mathrm{~Hz}), 6.45(\mathrm{dd}, .80 \mathrm{H}, \mathrm{J}=4,12 \mathrm{~Hz}), 4.51-4.61(\mathrm{~m}, 2 \mathrm{H}), 4.12-4.34(\mathrm{~m}, 2.20$ $\mathrm{H}), 3.99(\mathrm{dd}, .80 \mathrm{H}, \mathrm{J}=4,16 \mathrm{~Hz}), 3.50(\mathrm{dd}, .80 \mathrm{H}, \mathrm{J}=11,16 \mathrm{~Hz}), 3.24(\operatorname{app~t}, .20 \mathrm{H}, \mathrm{J}=13$ $\mathrm{Hz}$ ), 2.88 (ddd, .20 H, J=6, 8, $14 \mathrm{~Hz}$ ), 2.65 (ddd, .80 H, J=4, 8, $14 \mathrm{~Hz}$ ), 1.79-2.06 (m, $3 \mathrm{H}), 1.23-1.69(\mathrm{~m}, 4 \mathrm{H}) .{ }^{13} \mathrm{C} \mathrm{NMR}$ for the major rotamer $\left(100 \mathrm{MHz}, \mathrm{CDCl}_{3}\right): \delta 184.99$, 173.57, 158.39 (q, J=36 Hz), 116.68 (q, J=285 Hz), 66.92, 60.31, 47.26, 45.67 (q, J=3 $\mathrm{Hz}), 30.81,28.63,28.46,26.32 . \mathrm{mp}=157{ }^{\circ} \mathrm{C} . \quad \mathrm{IR}\left(\mathrm{cm}^{-1}\right)$ 3397, 1704, 1679, 1377. HRMS m/z calcd for $\mathrm{C}_{12} \mathrm{H}_{15} \mathrm{~F}_{3} \mathrm{~N}_{2} \mathrm{O}_{3} \mathrm{SNa}^{+}$: 347.0647 ; found: 347.0653

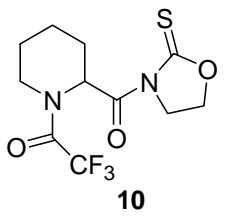

Compound $\mathbf{1 0}$ was prepared in $88 \%$ overall yield from the amino acid. Tetramethylguanidine (1.0 equiv) was used as the base in the TFA protection.

${ }^{1} \mathrm{H}$ NMR revealed a 3.4:1 mixture of two conformers $\left(400 \mathrm{MHz}, \mathrm{CDCl}_{3}\right): \delta 6.92$ $(\mathrm{d}, .23 \mathrm{H}, \mathrm{J}=7 \mathrm{~Hz}), 6.68(\mathrm{dd}, .77 \mathrm{H}, \mathrm{J}=4,7 \mathrm{~Hz}), 4.46-4.65(\mathrm{~m}, 2 \mathrm{H}), 4.24-4.32(\mathrm{~m}, 1 \mathrm{H})$, 4.12-4.19 (m, 1H), 3.86-3.90 (m, 1H), 3.74-3.81 (m, .77H), 3.43-3.52 (m, .23H), 2.18$2.34(\mathrm{~m}, 1 \mathrm{H}), 1.31-2.04(\mathrm{~m}, 5 \mathrm{H}) .{ }^{13} \mathrm{C} \mathrm{NMR}$ for the major rotamer $\left(100 \mathrm{MHz}, \mathrm{CDCl}_{3}\right): \delta$ 184.80, 172.21, 157.80 (q, J=36 Hz), 116.54 (q, J=286 Hz), 66.93, 53.83, 47.42, 44.28 (q, $\mathrm{J}=4 \mathrm{~Hz}), 26.58,24.54,19.90 . \mathrm{mp}=132{ }^{\circ} \mathrm{C} . \mathrm{IR}\left(\mathrm{cm}^{-1}\right) 2951,1686,1376,1332$. HRMS $\mathrm{m} / \mathrm{z}$ calcd for $\mathrm{C}_{11} \mathrm{H}_{13} \mathrm{~F}_{3} \mathrm{~N}_{2} \mathrm{O}_{3} \mathrm{SH}^{+}$: 311.0671 ; found: 311.0675



Compound 11 was prepared in $76 \%$ overall yield from the amino acid. Triethylamine (1.0 equiv) was used as the base in the TFA protection.

${ }^{1} \mathrm{H}$ NMR revealed a 7.3:1 mixture of two conformers $\left(400 \mathrm{MHz}, \mathrm{CDCl}_{3}\right): \delta 6.71$, 
(bm, .12H), 6.27 (dd, .88 H, J=4, $9 \mathrm{~Hz}), 4.54-4.62(\mathrm{~m}, 2 \mathrm{H}), 4.13-4.32(\mathrm{~m}, 2 \mathrm{H}), 3.68-3.94$ $(\mathrm{m}, 2 \mathrm{H}), 2.42-2.57(\mathrm{~m}, 1 \mathrm{H}), 2.03-2.16(\mathrm{~m}, 3 \mathrm{H}) .{ }^{13} \mathrm{C} \mathrm{NMR}$ for the major rotamer $(100$ $\left.\mathrm{MHz}, \mathrm{CDCl}_{3}\right): \delta 185.31,171.76,155.73(\mathrm{q}, \mathrm{J}=38 \mathrm{~Hz}), 116.28(\mathrm{q}, \mathrm{J}=285 \mathrm{~Hz}), 67.35$, 60.77, 48.14 (q, J=3 Hz), 47.83, 29.34, 24.86. $\mathrm{mp}=124-126{ }^{\circ} \mathrm{C}$. IR $\left(\mathrm{cm}^{-1}\right) 2985,1688$, 1375, 1328. HRMS m/z calcd for $\mathrm{C}_{10} \mathrm{H}_{11} \mathrm{~F}_{3} \mathrm{~N}_{2} \mathrm{O}_{3} \mathrm{SH}^{+}$: 297.0515; found: 297.0523

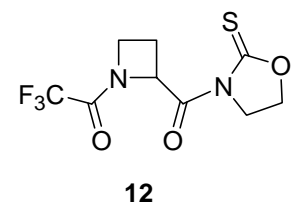

Compound 12 was prepared in $87 \%$ overall yield from the amino acid. Triethylamine (1.0 equiv) was used as the base in the TFA protection. This compound was isolated as a white foam and then as a clear oil upon heating and subjection to vacuum.

${ }^{1} \mathrm{H}$ NMR revealed a 3.1:1 mixture of conformers $\left(500 \mathrm{MHz}, \mathrm{CDCl}_{3}\right): \delta 6.49-6.52$ $(\mathrm{m}, .24 \mathrm{H}), 6.28(\mathrm{dd}, .75 \mathrm{H}, \mathrm{J}=6,10 \mathrm{~Hz}), 4.58-4.68(\mathrm{~m}, 2 \mathrm{H}), 4.00-4.44(\mathrm{~m}, 4 \mathrm{H}), 2.95-3.10$ $(\mathrm{m}, 1 \mathrm{H}), 2.23-2.35(\mathrm{~m}, 1 \mathrm{H}) .{ }^{13} \mathrm{C}$ NMR for the major rotamer $\left(100 \mathrm{MHz}, \mathrm{CDCl}_{3}\right): \delta$ 185.02, 168.61, 155.96 (q, J=38 Hz), 116.05 (q, J=286 Hz), 68.00, 61.53, 49.40, 47.03. IR $\left(\mathrm{cm}^{-1}\right)$ 1700, 1471, 1388. HRMS m/z calcd for $\mathrm{C}_{9} \mathrm{H}_{9} \mathrm{~F}_{3} \mathrm{~N}_{2} \mathrm{O}_{3} \mathrm{SNa}^{+}$: 305.0178; found: 305.0181

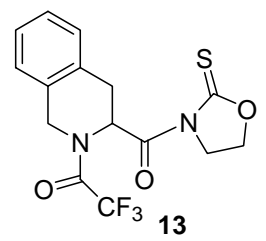

Compound 13 was prepared in $87 \%$ overall yield from the amino acid hydrochloride salt. Tetramethylguanidine (3.0 equiv) was used as the base in the TFA protection, and 2.05 equiv of ethyltrifluoroacetate were used.

${ }^{1} \mathrm{H}$ NMR revealed a 3:1 mixture of conformers $\left(400 \mathrm{MHz}, \mathrm{CDCl}_{3}\right): \delta$ 7.18-7.35 (m, 4H), $7.10(\mathrm{~d}, .25 \mathrm{H}, \mathrm{J}=8 \mathrm{~Hz}), 6.55(\mathrm{dd}, .75 \mathrm{H}, \mathrm{J}=6,8 \mathrm{~Hz}), 4.88(\mathrm{~s}, .25 \mathrm{H}), 4.80$ (dd, $1.50 \mathrm{H}, \mathrm{J}=15,26 \mathrm{~Hz}), 4.55-4.60(\mathrm{~m}, 2 \mathrm{H}), 4.48(\mathrm{dd}, .25 \mathrm{H}, \mathrm{J}=9,18 \mathrm{~Hz}), 4.23-4.30(\mathrm{~m}, 1 \mathrm{H})$, 4.08-4.17 (m, 1H), $3.87(\mathrm{ddd}, .25 \mathrm{H}, \mathrm{J}=6,9,15 \mathrm{~Hz}), 3.58(\mathrm{dd}, .75 \mathrm{H}, \mathrm{J}=6,16 \mathrm{~Hz}), 3.42$ (ddd, $.50 \mathrm{H}, \mathrm{J}=3,17,26 \mathrm{~Hz}), 3.13(\mathrm{dd}, .75 \mathrm{H}, \mathrm{J}=8,15 \mathrm{~Hz}) .{ }^{13} \mathrm{C}$ NMR for the major rotamer $\left(100 \mathrm{MHz}, \mathrm{CDCl}_{3}\right): \delta 185.17,171.78,158.31(\mathrm{q}, \mathrm{J}=36 \mathrm{~Hz}), 133.24,132.76,128.73$, 128.00, 127.91, 126.00, 116.47 (q, J=285 Hz), 67.23, 55.24, 47.40, 46.87 (q, J=4 Hz), 30.64. $\mathrm{mp}=74-76{ }^{\circ} \mathrm{C}$. IR $\left(\mathrm{cm}^{-1}\right) \quad 1686,1375,1330$. HRMS $\mathrm{m} / \mathrm{z}$ calcd for $\mathrm{C}_{15} \mathrm{H}_{13} \mathrm{~F}_{3} \mathrm{~N}_{2} \mathrm{O}_{3} \mathrm{SH}^{+}$: 359.0671; found: 359.0667 


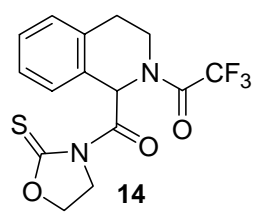

Compound 14 was prepared in 63\% overall yield from 1-isoquinolinecarboxylic acid. In the reduction of 1 -isoquinolinecarboxylic acid by the method of Shuman, it was observed that increasing the pressure of $\mathrm{H}_{2}$ from 40 to $75 \mathrm{psi}$, and allowing the reaction to stir for two days afforded nearly quantitative yield. Tetramethylguanidine (3.0 equiv) was used as the base in the TFA protection, and 2.05 equiv of ethyltrifluoroacetate were used.

${ }^{1} \mathrm{H}$ NMR revealed a 30:1 mixture of conformers, for the major rotamer $(400 \mathrm{MHz}$, $\left.\mathrm{CDCl}_{3}\right): \delta 8.35(\mathrm{~s}, 1 \mathrm{H}), 6.64(\mathrm{~d}, 1 \mathrm{H}, \mathrm{J}=7 \mathrm{~Hz}), 7.19-7.30(\mathrm{~m}, 3 \mathrm{H}), 4.56-4.63(\mathrm{~m}, 1 \mathrm{H}), 4.50$ (app q, 1H J=9 Hz), 4.30 (ddd, 1H, J=8, 10, $11 \mathrm{~Hz}), 4.15-4.21(\mathrm{~m}, 1 \mathrm{H}), 4.07$ (ddd, 1H, $\mathrm{J}=6,9,11 \mathrm{~Hz}), 3.75$ (ddd, 1H, J=4, 9, $16 \mathrm{~Hz}$ ), 3.25 (ddd, 1H, 4, 9, $15 \mathrm{~Hz}), 2.90$ (ddd, 1H, $\mathrm{J}=4,6,16 \mathrm{~Hz}) .{ }^{13} \mathrm{C} \mathrm{NMR}$ for the major rotamer: $\left(100 \mathrm{MHz}, \mathrm{CDCl}_{3}\right): \delta 185.61,172.03$, 157.50 (q, J=37 Hz), 135.55, 129.52, 128.95, 128.60, 127.60, 127.15, 116.43 (q, J=285 $\mathrm{Hz}$ ), 66.57, 55.19, 47.63, 43.18 (q, J=4 Hz), 29.21. $\mathrm{mp}=80-82{ }^{\circ} \mathrm{C} . \quad$ IR $\left(\mathrm{cm}^{-1}\right) 1688$, 1375, 1333. HRMS m/z calcd for $\mathrm{C}_{15} \mathrm{H}_{13} \mathrm{~F}_{3} \mathrm{~N}_{2} \mathrm{O}_{3} \mathrm{SH}^{+}$: 359.0671 ; found: 359.0677

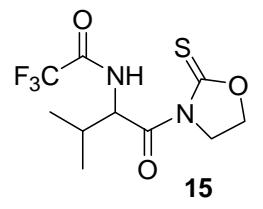

Compound 15 was prepared in $74 \%$ overall yield from the amino acid. Triethylamine (1.0 equiv) was used as the base in the TFA protection.

${ }^{1} \mathrm{H}$ NMR (400 MHz, $\mathrm{CDCl}_{3}$ ): $\delta 6.86(\mathrm{br} \mathrm{d}, 1 \mathrm{H}, \mathrm{J}=8 \mathrm{~Hz}), 6.73(\mathrm{dd}, 1 \mathrm{H}, \mathrm{J}=3,9 \mathrm{~Hz})$, 4.53-4.65 (m, 2H), 4.29 (ddd, 1H, J=9, 10, $11 \mathrm{~Hz}$ ), 4.18 (ddd, 1H, J=6, 9, $11 \mathrm{~Hz}$ ), 2.50 (hd, $1 \mathrm{H}, \mathrm{J}=3,7 \mathrm{~Hz}), 1.06(\mathrm{~d}, 3 \mathrm{H}, \mathrm{J}=7 \mathrm{~Hz}), 0.85$ (d, 3H, J=7Hz). ${ }^{13} \mathrm{C}$ NMR $(100 \mathrm{MHz}$, $\mathrm{CDCl}_{3}$ ): $\delta 184.70,171.83,157.19$ (q, J=37 Hz), 115.88 (q, J=286 Hz), 67.06, 55.75, 47.30, 31.05, 19.60, 15.55. $\mathrm{mp}=130{ }^{\circ} \mathrm{C}$. IR $\left(\mathrm{cm}^{-1}\right)$ 3343, 1721, 1689, 1368. HRMS $\mathrm{m} / \mathrm{z}$ calcd for $\mathrm{C}_{10} \mathrm{H}_{13} \mathrm{~F}_{3} \mathrm{~N}_{2} \mathrm{O}_{3} \mathrm{SH}^{+}$: 299.0671; found: 299.0678

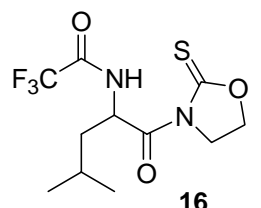

Compound 16 was prepared in $70 \%$ overall yield from the amino acid. Triethylamine (1.0 equiv) was used as the base in the TFA protection. This compound was flashed using neutal silica.

${ }^{1} \mathrm{H}$ NMR (400 MHz, $\left.\mathrm{CDCl}_{3}\right): \delta 6.90(\mathrm{~d}, 1 \mathrm{H}, \mathrm{J}=5 \mathrm{~Hz}), 6.67-6.73$ (ddd, 1H, J=3, 8, 
$11 \mathrm{~Hz}), 4.53-4.64$ (m, 2H), 4.13-4.30 (m, 2H), 1.91 (ddd, 1H, J=3, 10, $14 \mathrm{~Hz}), 1.66-1.75$ $(\mathrm{m}, 1 \mathrm{H}), 1.52(\mathrm{ddd}, 1 \mathrm{H}, \mathrm{J}=4,11,14 \mathrm{~Hz}), 1.02(\mathrm{~d}, 3 \mathrm{H}, \mathrm{J}=7 \mathrm{~Hz}), 0.931(\mathrm{~d}, 3 \mathrm{H}, \mathrm{J}=7 \mathrm{~Hz})$. ${ }^{13} \mathrm{C}$ NMR $\left(100 \mathrm{MHz}, \mathrm{CDCl}_{3}\right): \delta$ 184.39, 173.36, 156.99 (q, J=37 Hz), 115.89 (q, J=286 $\mathrm{Hz}), 67.07,51.17,47.47,41.02,25.47,23.62,21.45 . \mathrm{mp}=146^{\circ} \mathrm{C} . \quad \mathrm{IR}\left(\mathrm{cm}^{-1}\right) 3329$, 1709, 1689, 1374. HRMS m/z calcd for $\mathrm{C}_{11} \mathrm{H}_{15} \mathrm{~F}_{3} \mathrm{~N}_{2} \mathrm{O}_{3} \mathrm{SH}^{+}: 313.0828$; found: 313.0830

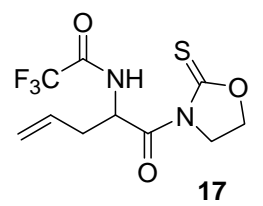

Compound 17 was prepared in $40 \%$ overall yield from the amino acid. Triethylamine (1.0 equiv) was used as the base in the TFA protection. The DCC coupling was performed at $0{ }^{\circ} \mathrm{C}$.

${ }^{1} \mathrm{H}$ NMR $\left(400 \mathrm{MHz}, \mathrm{CDCl}_{3}\right)$ : $\delta 6.97(\mathrm{~d}, 1 \mathrm{H}, \mathrm{J}=6 \mathrm{~Hz}), 6.66(\mathrm{ddd}, 1 \mathrm{H}, \mathrm{J}=4,8,8$ $\mathrm{Hz}), 5.64-5.75(\mathrm{~m}, 1 \mathrm{H}), 5.14-5.20(\mathrm{~m}, 2 \mathrm{H}), 4.54-4.65(\mathrm{~m}, 2 \mathrm{H}), 4.14-4.32(\mathrm{~m}, 2 \mathrm{H}), 2.83-$ $2.89(\mathrm{~m}, 1 \mathrm{H}), 2.51($ app p $, 1 \mathrm{H}, \mathrm{J}=8 \mathrm{~Hz}) .{ }^{13} \mathrm{C}$ NMR $\left(100 \mathrm{MHz}, \mathrm{CDCl}_{3}\right): \delta$ 184.61, 171.60, 156.73 (q, J=37 Hz), 131.13, 126.60, 115.78 (q, J=286 Hz), 67.19, 51.49, 47.38, 36.49. $\mathrm{mp}=132{ }^{\circ} \mathrm{C} . \quad \operatorname{IR}\left(\mathrm{cm}^{-1}\right) 3313,1712,1695,1373$. HRMS $\mathrm{m} / \mathrm{z}$ calcd for $\mathrm{C}_{10} \mathrm{H}_{11} \mathrm{~F}_{3} \mathrm{~N}_{2} \mathrm{O}_{3} \mathrm{SH}^{+}:$297.0515; found: 297.0522

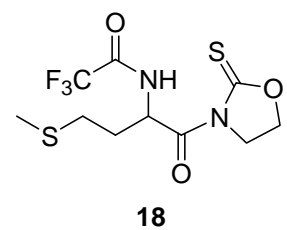

Compound 18 was prepared in $88 \%$ overall yield from the amino acid. Triethylamine (1.0 equiv) was used as the base in the TFA protection.

${ }^{1} \mathrm{H}$ NMR (400 MHz, $\left.\mathrm{CDCl}_{3}\right): \delta 7.32,(\mathrm{~d}, 1 \mathrm{H}), 6.62(\mathrm{ddd}, 1 \mathrm{H}, \mathrm{J}=4,9,17 \mathrm{~Hz}), 4.57-$ 4.65 (m, 2H), 4.29 (ddd, $1 \mathrm{H}, \mathrm{J}=8,9,12 \mathrm{~Hz}), 4.22$ (ddd, 1H, J=8, 9, $12 \mathrm{~Hz}$ ), 2.66 (ddd, $1 \mathrm{H}$, $\mathrm{J}=6,9,14 \mathrm{~Hz}), 2.51-2.56(\mathrm{~m}, 1 \mathrm{H}), 2.10(\mathrm{~s}, 3 \mathrm{H}), 1.96-2.03(\mathrm{~m}, 1 \mathrm{H}) .{ }^{13} \mathrm{C} \mathrm{NMR}(100 \mathrm{MHz}$, $\left.\mathrm{CDCl}_{3}\right): \delta 184.58,171.66,157.09(\mathrm{q}, \mathrm{J}=38 \mathrm{~Hz}), 115.79(\mathrm{q}, \mathrm{J}=286 \mathrm{~Hz}), 67.22,52.26$, 47.49, 31.89, 30.02, 15.91. $\mathrm{mp}=150-151^{\circ} \mathrm{C} . \quad$ IR $\left(\mathrm{cm}^{-1}\right) 3293,1716,1698,1378$. HRMS m/z calcd for $\mathrm{C}_{10} \mathrm{H}_{13} \mathrm{~F}_{3} \mathrm{~N}_{2} \mathrm{O}_{3} \mathrm{~S}_{2} \mathrm{Na}^{+}$: 353.0211 ; found: 353.0216 


\section{Typical Procedure for the Kinetic Resolutions}

All entries in Table 1 were determined by averaging the s-factors from both runs, however the enatiomeric excess and \% conversion data reported are from individual runs.



Table 1, Entry 2: A mixture of thioimide $10(86.8 \mathrm{mg}, 0.2797 \mathrm{mmol})$ and benzo[k]fluoranthene $(279 \mu \mathrm{L}, 0.025 \mathrm{M}$ solution in toluene, $0.000699 \mathrm{mmol}$, internal standard) was dissolved in toluene $(1.4 \mathrm{ml})$, and cooled to $0{ }^{\circ} \mathrm{C}$. Methanol $(340 \mu \mathrm{L}, 8.40$ mmol) was added and stirred until solution became homogenous, at which point the first aliquot is taken. Catalyst $2(6.92 \mathrm{mg}, 0.02797 \mathrm{mmol})$ was then added as a solution in toluene $(70 \mu \mathrm{L})$ and the reaction stirred at $0{ }^{\circ} \mathrm{C}$ while monitoring by HPLC analysis as follows. $2 \mu \mathrm{L}$ Aliquots of the reaction were taken and diluted with $200 \mu \mathrm{l}$ of a 1:1 hexanes - ethanol solution, $50 \mu 1$ of which were directly injected onto a chiralcel OD column. For some compounds, the liberated oxazolidinethione would co-elute with one or both enantiomers of starting material. In these cases a $10 \mu \mathrm{L}$ aliquot was flashed using a pipet column, and eluting 3 column volumes with 1:1 hexanes/EtOAc. These conditions allow for complete separation of the starting material from oxazolidinethione without the need for TLC of the eluting solvent. $50 \mu \mathrm{L}$ of the eluent was then injected directly onto the column. Elution with 3:1 hexanes - isopropanol provided separation of all the reaction components, and the amount of starting material remaining was measured against the internal standard. The reaction was allowed to proceed for 71 hours, then an aliquot was taken to determine conversion, which was found to be $52.8 \%$. The reaction mixture was immediately purified by flash chromatography on silica $(5: 1 \rightarrow 2: 1$ hexanes - ethyl acetate) to provide recovered $\mathbf{1 0}(40.4 \mathrm{mg}, 100 \%$ of theory based on $52.8 \%$ conversion). The enantiomeric excess of the flashed recovered starting material was determined to be $98.9 \%$ (Chiralcel OD semi-preperative column, 3:1 hexanesisopropanol, flow rate $=1.5 \mathrm{~mL} / \mathrm{min}$, retention times $=30.5 \mathrm{~min}, 40.4 \mathrm{~min}$ ). An ee of $98.9 \%$ at $52.8 \%$ conversion corresponds to an s-factor of 83 .

A duplicate run provided recovered starting material of $99.5 \%$ ee at $53.1 \%$ conversion which corresponds to an s-factor of $89 .[\alpha]_{\mathrm{D}}=+23.5(\mathrm{c}=1.50$, EtOAc $)$.

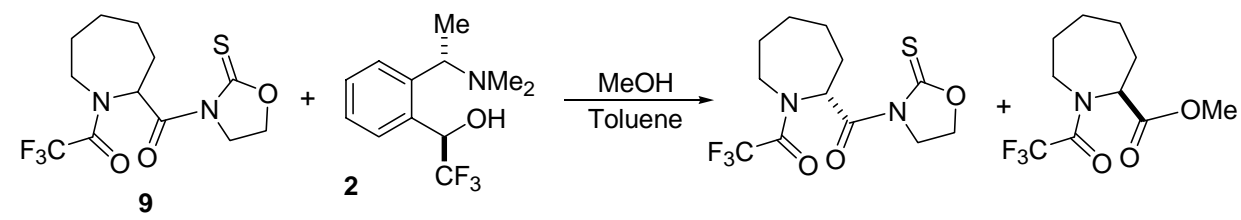

Table 1, Entry 1: The typical procedure was followed using $20.2 \mathrm{mg}(0.0623$ mmol) of compound $9,75 \mu \mathrm{L}(1.87 \mathrm{mmol})$ of $\mathrm{MeOH}$, and $1.54 \mathrm{mg}(0.00623 \mathrm{mmol})$ of catalyst 2. The reaction was stirred at room temperature for 54 hours ( $58 \%$ conversion), and flash chromatography provided $8.2 \mathrm{mg}$ ( $97 \%$ of theory) of recovered 9 of $95.8 \%$ ee (Chiralcel OD semi-preperative column, $3: 1$ hexanes-isopropanol, flow rate $=1.5 \mathrm{~mL} /$ 
$\min$, retention times $=27.6 \mathrm{~min}, 43.1 \mathrm{~min}),[\alpha]_{\mathrm{D}}=+93.6(\mathrm{c}=0.81$, EtOAc $)$. An ee of $95.8 \%$ at $58.0 \%$ conversion corresponds to an s-factor of 20.6 .

A duplicate run provided recovered 9 in $85.8 \%$ ee at $53.0 \%$ conversion which corresponds to an s-factor of 19.7 .

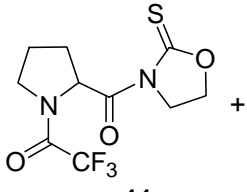

11

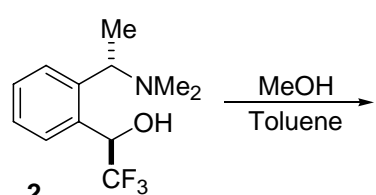

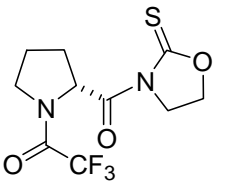

${ }_{0}^{\mathrm{N}}$

Table 1, Entry 3: The typical procedure was followed using $53.4 \mathrm{mg}(0.1802$ $\mathrm{mmol})$ of compound 11, $219 \mu \mathrm{L}(5.407 \mathrm{mmol})$ of $\mathrm{MeOH}$, and $4.46 \mathrm{mg}(0.01802 \mathrm{mmol})$ of catalyst 2. The reaction was stirred at room temperature for 99 hours $(58.2 \%$ conversion), and flash chromatography provided $22.0 \mathrm{mg}$ ( $99 \%$ of theory) of recovered 11 of $97.8 \%$ ee (Chiralcel OD semi-preperative column, 2:1 hexanes-isopropanol, flow rate $=1.5 \mathrm{~mL} / \mathrm{min}$, retention times $=25.9 \mathrm{~min}, 98.9 \mathrm{~min}),[\alpha]_{\mathrm{D}}=+146.7(\mathrm{c}=2.2$, EtOAc). An ee of $97.8 \%$ at $58.2 \%$ conversion corresponds to an s-factor of 25 .

A duplicate run provided recovered 11 in $93.9 \%$ ee at $57.5 \%$ conversion which corresponds to an s-factor of 19.<smiles>COC(=O)[C@@H]1CCN1C(=O)C(F)(F)F</smiles>

Table 1, Entry 4: The typical procedure was followed using $28.8 \mathrm{mg}(0.1020$ mmol) of compound 12, $124 \mu \mathrm{L}(3.06 \mathrm{mmol})$ of $\mathrm{MeOH}$, and $2.52 \mathrm{mg}(0.01020 \mathrm{mmol})$ of catalyst 2 . The reaction was stirred at $0{ }^{\circ} \mathrm{C}$ for 30 hours (54\% conversion), and HPLC shows a nearly equal rate of reaction for each enantiomer (Chiralcel OD semi-preperative column, $2: 1$ hexanes-isopropanol, flow rate $=1.5 \mathrm{~mL} / \mathrm{min}$, retention times $=36.6 \mathrm{~min}$, $152.4 \mathrm{~min}$ ), An ee of $3 \%$ at $54.0 \%$ conversion corresponds to an s-factor of 1.1 .

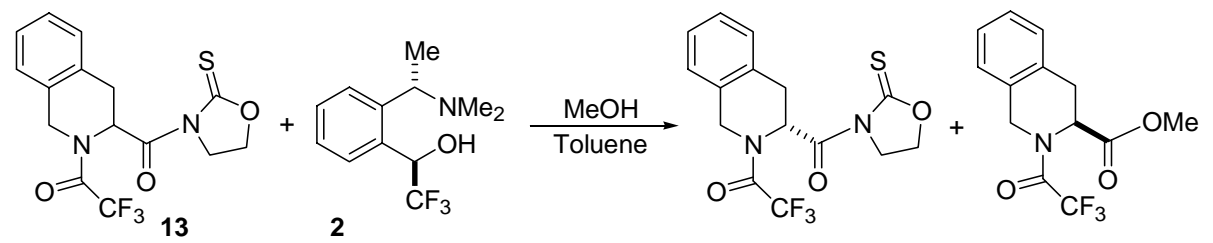

Table 1, Entry 5: The typical procedure was followed using $44.2 \mathrm{mg}(0.1233$ mmol) of compound 13, $150 \mu \mathrm{L}(3.699 \mathrm{mmol})$ of $\mathrm{MeOH}$, and $3.05 \mathrm{mg}(0.01233 \mathrm{mmol})$ of catalyst 2 . The reaction was stirred at $0{ }^{\circ} \mathrm{C}$ for 72 hours $(52.0 \%$ conversion), and flash chromatography provided $20.5 \mathrm{mg}$ ( $97 \%$ of theory) of recovered 13 of $92.1 \%$ ee (Chiralcel OD semi-preperative column, 3:1 hexanes-isopropanol, flow rate $=1.5 \mathrm{~mL}$ / min retention times $=43.5 \mathrm{~min}, 70.6 \mathrm{~min}$ ). An ee of $92.1 \%$ at $52.0 \%$ conversion corresponds to an s-factor of 40 . 
A duplicate run provided recovered 13 in $92.9 \%$ ee at $52.2 \%$ conversion which corresponds to an s-factor of $42 .[\alpha]_{\mathrm{D}}=+133.7(\mathrm{c}=1.30$, EtOAc)

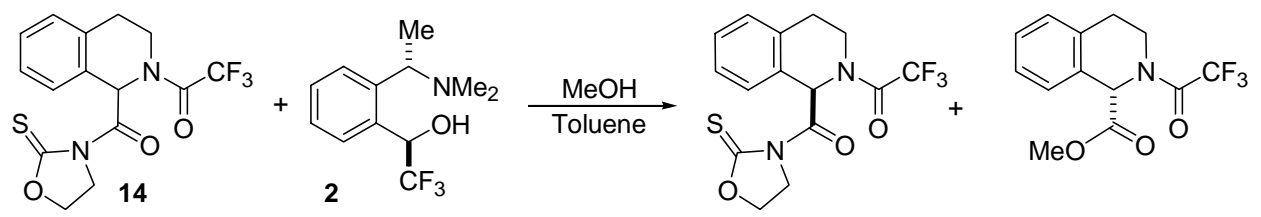

Table 1, Entry 6: The typical procedure was followed using $50.4 \mathrm{mg}(0.14065$ $\mathrm{mmol})$ of compound 14, $171 \mu \mathrm{L}(4.220 \mathrm{mmol})$ of $\mathrm{MeOH}$, and $3.48 \mathrm{mg}(0.014065 \mathrm{mmol})$ of catalyst 2 . The reaction was stirred at $0{ }^{\circ} \mathrm{C}$ for 55 hours $(53.9 \%$ conversion), and flash chromatography provided $23.0 \mathrm{mg}$ (99\% of theory) of recovered 14 of $96.2 \%$ ee (Chiralcel OD semi-preperative column, 3:1 hexanes-isopropanol, flow rate $=1.5 \mathrm{~mL}$ / $\min$ retention times $=35.8 \mathrm{~min}, 63.8 \mathrm{~min}),[\alpha]_{\mathrm{D}}=+239.4(\mathrm{c}=2.28$, EtOAc $)$. An ee of $96.2 \%$ at $53.9 \%$ conversion corresponds to an s-factor of 40 .

A duplicate run provided recovered 14 in $95.5 \%$ ee at $53.8 \%$ conversion which corresponds to an s-factor of 39.

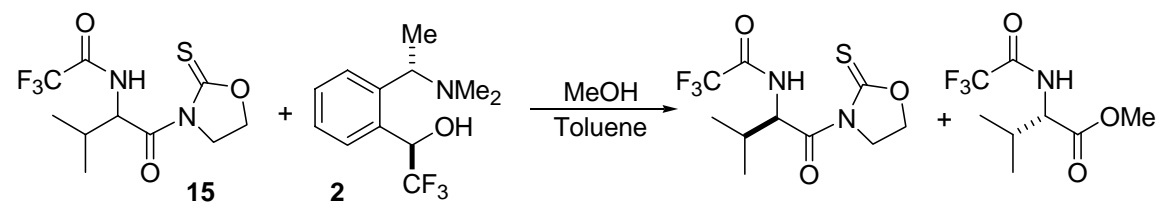

Table 1, Entry 7: The typical procedure was followed using $46.3 \mathrm{mg}(0.1552$ $\mathrm{mmol})$ of compound $15,189 \mu \mathrm{L}(4.656 \mathrm{mmol})$ of $\mathrm{MeOH}$, and $3.84 \mathrm{mg}(0.01552 \mathrm{mmol})$ of catalyst 2 . The reaction was stirred at $0{ }^{\circ} \mathrm{C}$ for 38 hours ( $54.9 \%$ conversion), and flash chromatography provided $20.8 \mathrm{mg}$ (99\% of theory) of recovered $\mathbf{1 5}$ of $90.0 \%$ ee (Chiralcel OD semi-preperative column, 4:1 hexanes-isopropanol, flow rate $=1.5 \mathrm{~mL}$ / min, retention times $=37.7 \mathrm{~min}, 48.5 \mathrm{~min}),[\alpha]_{\mathrm{D}}=-26.4(\mathrm{c}=2.08$, EtOAc $)$. An ee of $90.0 \%$ at $54.6 \%$ conversion corresponds to an s-factor of 20 .

A duplicate run provided recovered 15 in $87.3 \%$ ee at $53.3 \%$ conversion which corresponds to an s-factor of 21 .



Table 1, Entry 8: The typical procedure was followed using $47.5 \mathrm{mg}(0.1521$ $\mathrm{mmol})$ of compound $16,185 \mu \mathrm{L}(4.56 \mathrm{mmol})$ of $\mathrm{MeOH}$, and $3.76 \mathrm{mg}(0.01521 \mathrm{mmol})$ of catalyst 2. The reaction was stirred at $-26^{\circ} \mathrm{C}$ for 25 hours $(54.5 \%$ conversion), and flash chromatography on neutral silica provided $21.1 \mathrm{mg}$ (98\% of theory) of recovered 16 of 99.7\% ee (Chiralcel OD semi-preperative column, 4:1 hexanes-isopropanol, flow rate = $1.5 \mathrm{~mL} / \mathrm{min}$, retention times $=25.8 \mathrm{~min}, 66.5 \mathrm{~min}),[\alpha]_{\mathrm{D}}=+29.7(\mathrm{c}=2.11$, EtOAc $)$. An ee of $99.7 \%$ at $54.5 \%$ conversion corresponds to an s-factor of 69 .

A duplicate run provided recovered 16 in $99.1 \%$ ee at $53.8 \%$ conversion which 
corresponds to an s-factor of 66.

Table 1, Entry 9: This run was conducted using 5\% catalyst loading. The typical procedure was followed using $89.9 \mathrm{mg}(0.2879 \mathrm{mmol})$ of compound $16,350 \mu \mathrm{L}$ $(8.64 \mathrm{mmol})$ of $\mathrm{MeOH}$, and $3.56 \mathrm{mg}(0.01439 \mathrm{mmol})$ of catalyst 2 . The reaction was stirred at $-26^{\circ} \mathrm{C}$ for 50 hours $(56.8 \%$ conversion), and flash chromatography on neutral silica provided $37.1 \mathrm{mg}$ (96\% of theory) of recovered 16 of $99.97 \%$ ee (Chiralcel OD semi-preperative column, 4:1 hexanes-isopropanol, flow rate $=1.5 \mathrm{~mL} / \mathrm{min}$, retention times $=25.8 \mathrm{~min}, 66.5 \mathrm{~min}),[\alpha]_{\mathrm{D}}=+29.7(\mathrm{c}=2.11$, EtOAc $)$. An ee of $99.97 \%$ at $56.8 \%$ conversion corresponds to an s-factor of 61 .

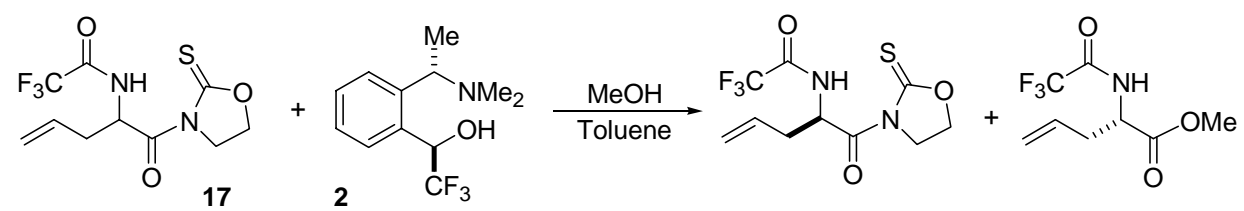

Table 1, Entry 10: The typical procedure was followed using $40.1 \mathrm{mg}(0.1353$ $\mathrm{mmol})$ of compound $17,165 \mu \mathrm{L}(4.06 \mathrm{mmol})$ of $\mathrm{MeOH}$, and $3.35 \mathrm{mg}(0.01353 \mathrm{mmol})$ of catalyst 2 . The reaction was stirred at $-26{ }^{\circ} \mathrm{C}$ for 7 hours $(53.9 \%$ conversion $)$, and flash chromatography on neutral silica provided $17.6 \mathrm{mg}$ ( $96 \%$ of theory) of recovered 17 of 98.7\% ee (Chiralcel OD semi-preperative column, 3:1 hexanes-isopropanol, flow rate $=$ $1.5 \mathrm{~mL} / \mathrm{min}$, retention times $=30.1 \mathrm{~min}, 47.4 \mathrm{~min}),[\alpha]_{\mathrm{D}}=+3.81(\mathrm{c}=1.65$, EtOAc $)$. An ee of $98.9 \%$ at $53.9 \%$ conversion corresponds to an s-factor of 61 .

A duplicate run provided recovered 17 in $94.8 \%$ ee at $51.7 \%$ conversion which corresponds to an s-factor of 60 .
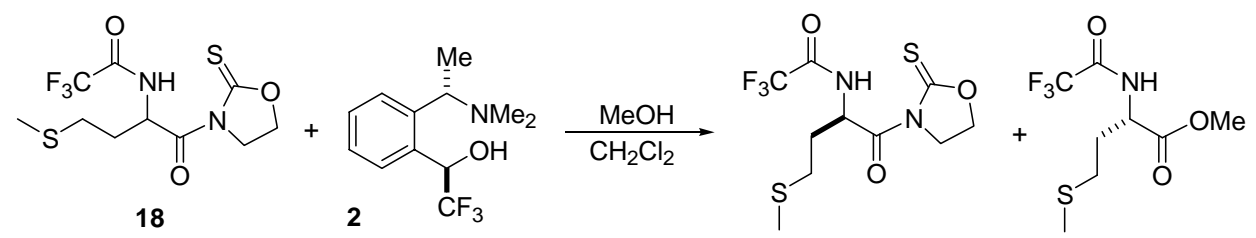

Table 1, Entry 11: The typical procedure was followed (except the reaction was conducted in methylene chloride at a concentration of $0.1 \mathrm{M}$ due to the insolubility of compound 18 using the typical conditions) using $73.2 \mathrm{mg}(0.2216 \mathrm{mmol})$ of compound $18,270 \mu \mathrm{L}(6.650 \mathrm{mmol})$ of $\mathrm{MeOH}$, and $5.48 \mathrm{mg}(0.02216 \mathrm{mmol})$ of catalyst 2 . The reaction was stirred at $-26^{\circ} \mathrm{C}$ for 7 hours ( $56 \%$ conversion), and flash chromatography provided $31.5 \mathrm{mg}$ ( $98 \%$ of theory) of recovered 18 of $98.1 \%$ ee (Chiralcel OD semipreperative column, $3: 1$ hexanes-isopropanol, flow rate $=1.5 \mathrm{~mL} / \mathrm{min}$, retention times $=$ $37.5 \mathrm{~min}, 82.3 \mathrm{~min}),[\alpha]_{\mathrm{D}}=+43.2(\mathrm{c}=0.64$, EtOAc). An ee of $98.1 \%$ at $56.0 \%$ conversion corresponds to an s-factor of 35 .

A duplicate run provided recovered 18 in $99.4 \%$ ee at $57.0 \%$ conversion which corresponds to an s-factor of 38.8 . 


\section{Peptide Coupling Reactions}

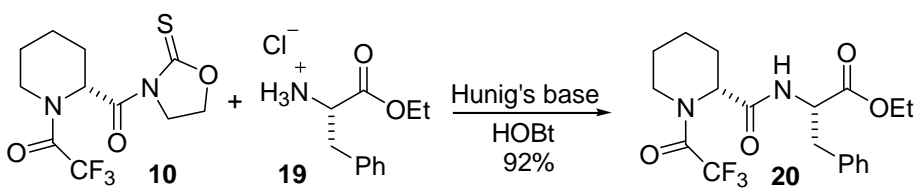

To a stirred solution of $36.0 \mathrm{mg}$ thioimide $10(0.1160 \mathrm{mmol})$ and $28.0 \mathrm{mg} \mathrm{L}$ phenylalanine ethyl ester hydrochloride $(0.1160 \mathrm{mmol})$ in $580 \mu \mathrm{L}$ THF $(0.2 \mathrm{M})$ at room temperature was added $101 \mu \mathrm{L}$ Hunig's base $(0.5800 \mathrm{mmol})$. The reaction mixture became homogenous, and $31.4 \mathrm{mg}$ HOBt $(0.2320 \mathrm{mmol})$ was added as a solid. After stirring at room temperature for 36 hours, the reaction was concentrated, and purification by flash chromatography (7:1 hexanes - ethyl acetate) provided the dipeptide $\mathbf{2 0}(42.7 \mathrm{mg}$, $92 \%$ ) as a white solid. The ee of the starting material was $>99 \%$ and the d.r. of the dipeptide was $>100: 1$. This was determined by an independent synthesis of the peptide N-TFA-DL-Pip-L-Phe-OEt and separation of the diastereomers using a Chiralcel OD column.

${ }^{1} \mathrm{H}$ NMR revealed a 4:1 mixture of conformers $\left(400 \mathrm{MHz}, \mathrm{CDCl}_{3}\right): \delta 7.23-7.30$ $(\mathrm{m}, 3 \mathrm{H}), 7.05-7.08(\mathrm{~m}, 2 \mathrm{H}), 6.13(\mathrm{~d}, 1 \mathrm{H}, \mathrm{J}=8 \mathrm{~Hz}), 5.07$ (br d, 0.8H, J=5 Hz), 4.81 (q, 1H, $\mathrm{J}=8 \mathrm{~Hz}), 4.51$ (br d, 0.2H, J=5 Hz), 4.39 (br d, 0.2H, J=14 Hz), $4.16(\mathrm{q}, 2 \mathrm{H}, \mathrm{J}=7 \mathrm{~Hz}), 3.83$ (br d, 0.8H, J=14 Hz), 3.20-3.28 (m, 0.8H), 3.09 (d, 1.6H, J=6 Hz), 3.04-3.17 (m, 0.2H), 2.35-2.38 (m, 0.2H), 2.21-2.27 (m, 0.8H), 1.39-1.70 (m, 5H), $1.26(\mathrm{t}, 0.6 \mathrm{H}, \mathrm{J}=7 \mathrm{~Hz}), 1.23$ $(\mathrm{t}, 2.4 \mathrm{H}, \mathrm{J}=7 \mathrm{~Hz}) .{ }^{13} \mathrm{C} \mathrm{NMR}$ for the major rotamer $\left(100 \mathrm{MHz}, \mathrm{CDCl}_{3}\right): \delta 171.29,168.65$, 157.46 (q, J=36 Hz), 135.52, 129.32, 128.94, 127.52, 116.55 (q, J=286 Hz), 61.85, 53.95, 53.04, 44.20 (q, J=3 Hz), 37.80, 25.78, 25.4, 20.26, 14.28. $\mathrm{mp}=100-101 . \quad \mathrm{IR}\left(\mathrm{cm}^{-1}\right)$ 3426, 1737, 1678, 1194. $[\alpha]_{\mathrm{D}}=+21.41(\mathrm{c}=1.49$, EtOAc). HRMS m/z calcd for $\mathrm{C}_{19} \mathrm{H}_{23} \mathrm{~F}_{3} \mathrm{~N}_{2} \mathrm{O}_{4} \mathrm{H}^{+}$: 401.1682 ; found: 401.1672

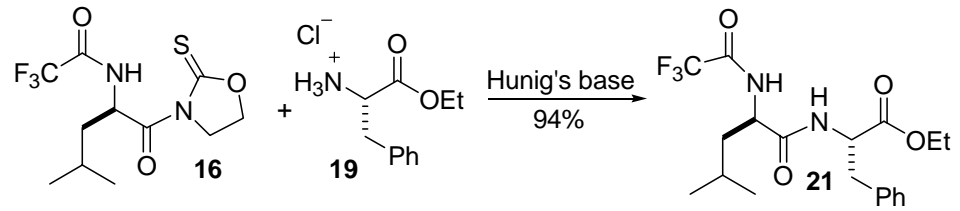

To a stirred solution of $53.0 \mathrm{mg}$ thioimide $16(0.1697 \mathrm{mmol})$ and $39.0 \mathrm{mg} \mathrm{L}-$ phenylalanine ethyl ester hydrochloride $(0.1697 \mathrm{mmol})$ in $1.7 \mathrm{ml}$ THF $(0.1 \mathrm{M})$ at room temperature was added $65.1 \mu \mathrm{L}$ Hunig's base $(0.3733 \mathrm{mmol})$. The reaction mixture became homogenous, and was refluxed for 36 hours. The reaction was then concentrated, and purification by flash chromatography (7:1 hexanes - ethyl acetate) provided the dipeptide $21(64.2 \mathrm{mg}, 94 \%)$ as a white solid. The ee of the starting material was $99 \%$ and the d.r. of the dipeptide was 98:2. This was determined by an independent synthesis of the peptide N-TFA-DL-Leu-L-Phe-OEt and separation of the diastereomers using a Chiralcel OD column.

${ }^{1} \mathrm{H}$ NMR (400 MHz, $\left.\mathrm{CDCl}_{3}\right): \delta$ 7.21-7.29 (m, 3H), 7.02-7.11 (m, 3H), 6.30-6.48 (m, 1H), 4.83(ddd, 2H, J=4, 6, $6 \mathrm{~Hz}), 4.41-4.48(\mathrm{~m}, 1 \mathrm{H}), 4.17$ (q, 2H, J=6 Hz), 3.17 (dd, $1 \mathrm{H}, 4 \mathrm{~Hz}), 3.00-3.04(\mathrm{~m}, 1 \mathrm{H}), 1.47$ (d, 2H, J=6 Hz), $1.41(1 \mathrm{H}, \mathrm{hd}, \mathrm{J}=5 \mathrm{~Hz}) 1.24(\mathrm{t}, 3 \mathrm{H}$, $\mathrm{J}=8 \mathrm{~Hz}), 0.85(\operatorname{app~t}, 6 \mathrm{H}, \mathrm{J}=5 \mathrm{~Hz}) .{ }^{13} \mathrm{C} \mathrm{NMR}\left(100 \mathrm{MHz}, \mathrm{CDCl}_{3}\right): \delta 171.42,170.35$, 
157.07 (q, $\mathrm{J}=37 \mathrm{~Hz}), 135.79,129.43,128.83,127.49$, 115.89 (q, J=286 Hz), 62.07, 53.47, $52.17,41.86,38.07,24.81,22.87,22.29,14.25 . \mathrm{mp}=89-91 . \mathrm{IR}\left(\mathrm{cm}^{-1}\right) 3270,1703,1655$ 1187. $[\alpha]_{\mathrm{D}}=+17.10\left(\mathrm{c}=1.18\right.$, EtOAc). HRMS m/z calcd for $\mathrm{C}_{19} \mathrm{H}_{25} \mathrm{~F}_{3} \mathrm{~N}_{2} \mathrm{O}_{4} \mathrm{H}^{+}$: 403.1839; found: 403.1840

\section{Determination of Absolute Configuration}

The absolute configurations of the recovered cyclic substrates $\mathbf{1 1}$ and $\mathbf{1 3}$ were determined by preparing authentic samples of the $\alpha$-trifluoroacetamido oxazolidinethione imides from the corresponding L-amino acids (proline and 1,2,3,4tetrahydroisoquinoline-3-carboxylic acid). The retention times of these materials were compared with that of our recovered starting materials, which showed that the faster reacting enantiomer is the L-amino acid-derived substrates. Thus, the recovered starting materials correspond to the D- amino acid-derived substrates. The absolute configurations of compounds 9, 10 and 14 were assigned by analogy. Furthermore, we observed that in all cases of the cyclic amino acid derivatives, using our HPLC method, the slower reacting enantiomer is the slower eluting enantiomer.

In the case of the valine-derived substrate 15, the absolute configuration of the methanolysis product (N-TFA-Val-OMe) was determined by comparing the optical rotation of this material with that reported in the literature (Lit: N-TFA-L-Val-OMe $[\alpha]_{D}^{24}=+33.4\left(\mathrm{c}=0.72, \mathrm{CH}_{2} \mathrm{Cl}_{2}\right){ }^{3}$ N-TFA-Val-OMe from our kinetic resolution: $[\alpha]^{24}$ $=+22.7\left(\mathrm{c}=1.1, \mathrm{CH}_{2} \mathrm{Cl}_{2}, 74.5 \%\right.$ ee $\left.)\right)$. Thus, the starting material recovered from substrate 15 is of the D-configuration. To determine the absolute configuration of the recovered leucine-derived substrate 16, N-TFA-L-Leu-L-Phe-OEt was prepared as was N-TFA-DL-Leu-L-Phe-OEt. An HPLC method was then developed to separate the diastereomers of the N-TFA-DL-Leu-L-Phe-OEt. Subjection of compound 21 to this HPLC method allowed us to assign this compound as N-TFA-D-Leu-L-Phe-OEt. Thus, the recovered starting material from compound $\mathbf{1 6}$ is also of the $\mathrm{D}$ configuration. The absolute configuration of substrates $\mathbf{1 7}$ and $\mathbf{1 8}$ were assigned by analogy. In the case of the acyclic amino acid substrates, using our HPLC method, the slow reacting enantiomer is always the faster eluting enantiomer.

3 Denmark, S. E.; Stavenger, R. A.; Faucher, A.; Edwards, J. P. J. Org. Chem. 1997, 62, 3375. 


\section{Protecting Group Swap}

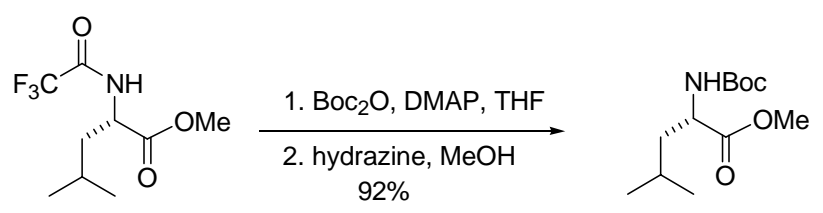

Using a slightly modified version of an amide to carbamate transformation reported by Burk, ${ }^{4}$ the trifluoracetamide can be converted to the $t$-butyl carbamate by the following procedure. To a stirred solution of the trifluroacetamide (44.9 $\mathrm{mg}, 0.1861$ mmol) and DMAP (4.5 mg, $0.03723 \mathrm{mmol})$ in THF $(930 \mu \mathrm{L}, 0.2 \mathrm{M})$ was added $\mathrm{Boc}_{2} \mathrm{O}$ $(85.5 \mu \mathrm{L}, 0.3723 \mathrm{mmol})$, and the solution was heated to reflux for 4 hours. After cooling to room temperature, $\mathrm{MeOH}(930 \mu \mathrm{L})$ and hydrazine $(23.4 \mu \mathrm{L}, 0.7440 \mathrm{mmol})$ were added and the solution was stirred for an additional hour. The reaction mixture was diluted with methylene chloride and the organic layer was washed with $1 \mathrm{M} \mathrm{HCl}, 1 \mathrm{M} \mathrm{CuSO}_{4}$, and sat. $\mathrm{NaHCO}_{3}$. The organic layer was dried over $\mathrm{MgSO}_{4}$, filtered, and concentrated at reduced pressure to a yellow oil. Purification by flash chromatography (10:1 hexanes:ethyl acetate) afforded the product as a clear oil $(41.9 \mathrm{mg}, 92 \%)$. There was no detectable racemization observed by $\mathrm{HPLC}$, and ${ }^{1} \mathrm{H}$ and ${ }^{13} \mathrm{C}$ NMR spectral data were in agreement with those reported in the literature. ${ }^{4}$ 


\section{Reaction Profile: \%Conversion vs. Time}

Kinetic resolutions which display s-factors greater than 10 will slow drastically as they approach $50 \%$ conversion. To illustrate this point, we have monitored the kinetic resolution of compound $\mathbf{1 6}$ by NMR with an enhanced catalyst loading of $15 \%$, as shown in the figure below. Because of the large difference in reactivities of the two enantiomeric substrates, there is a large window of time during which the reaction can be stopped without compromising the yield of recovered starting material.
